\title{
Lady Audley's Secret and the Portrayal of a Criminal Mind
}

\author{
Giuseppe Giordano \\ Department of Mental Health, ASL CN2 Alba-Bra, CN, Italy \\ Email: giugiordano1969@alice.it
}

How to cite this paper: Giordano, G. (2021). Lady Audley's Secret and the Portrayal of a Criminal Mind. Advances in Literary Study, 9, 127-134.

https://doi.org/10.4236/als.2021.93014

Received: April 12, 2021

Accepted: June 1, 2021

Published: June 4, 2021

Copyright $\odot 2021$ by author(s) and Scientific Research Publishing Inc. This work is licensed under the Creative Commons Attribution International License (CC BY 4.0).

http://creativecommons.org/licenses/by/4.0/

\begin{abstract}
Lady Audley's Secret is a novel first published in 1862 by Mary Elizabeth Braddon, a Victorian writer. It is the story of a young lady who, in her attempt to climb the social ladder, commits several crimes. Her behaviour was considered abnormal and improper in a society in which women had to be obedient and docile. The originality of this work is the representation of a woman whose behaviour was not considered as insane rather intentional and calculated but, despite this, she was confined to an asylum. Psychiatry was an emerging medical specialty during the Victorian period and the diagnosis of psychiatric conditions was not sophisticated and precise as today. The aim of this paper is to demonstrate that Lady Audley was likely affected by antisocial personality disorder according to the medical assessment criteria of the present time.
\end{abstract}

\section{Keywords}

Mary Elizabeth Braddon, Lady Audley, Psychopathy, Antisocial Personality, Crime

\section{Introduction}

Mary Elizabeth Braddon's Lady Audley's Secret is a Victorian novel that describes the story of a young lady who tries to escape poverty and a miserable life by performing criminal activities such as bigamy, child abandonment and attempted murders. All these illegal deeds were obviously considered at the time as dangerous, indecent and against social norms particularly when they were accomplished by women. The main role of women in society had to be maternal and loving as well as submissive and obedient to men and their place was mainly at home taking care of their husbands and children. Their liberty and autonomy were very limited and, according to the law in force, women's rights were para- 
doxically compared to those of criminals and insane people (Nsaidzedze, 2017). In Victorian society, a discrepancy between respect of social rules and aberrant behaviour was commonly associated with insanity and, in the most severe cases, criminal conduct. In the case of Lady Audley, Braddon describes her heroine as a person who was not affected by any kind of mental problem according to the advice of a medical expert. Even though she had been confined to an asylum to avoid either imprisonment or a family scandal, her behaviour was explained as a strong desire to improve her social position. Actually, she was a poor and unfortunate wife and mother of a little child but her ambition and personal wishes led her to reach a respectable position in society but not in accordance with acceptable standards and common rules. The aim of this article is to demonstrate that Lady Audley (henceforth, LA) was presumably affected by antisocial personality disorder since her behaviour was against social norms and obligations and more alike the conduct and disposition of a psychopath or a criminal. The relationship between criminal behaviour and this type of disorder has been well demonstrated in forensic and clinical settings (Davison, 2012), and the rationale of this investigation is to demonstrate that Braddon provides, on several occasions, clues and hints concerning the abnormality of her heroine's behaviour and of its antisocial disposition.

\section{Methodology}

A close reading of the novel has been made to analyse all those elements such as behaviour, attitudes, emotional reactions, facial expression and speech of the main character that are in relation to the personality traits displayed by an antisocial person. A personality trait can be defined as a stable and typical pattern of behaviour, emotion and thought. For what concerns antisocial personality, the traits frequently displayed are self-centredness, superficial and cold emotions, lack of remorse, grandiosity, seduction, manipulation, falseness, neglect of social rules, all these traits being a classical expression of psychopathy (Hare, 1996). Psychopathy and antisocial behaviour can be fundamentally considered as synonyms. These traits are also described by the Diagnostic and Statistical Manual of Mental Disorders Fifth Edition, DSM-5 (APA, 2012) which defines specific diagnostic criteria that must be fulfilled in order to make the diagnosis of antisocial personality disorder. Hence, the main final goal of this study is to demonstrate that the personality traits which emerge from the descriptions of LA do correspond to the DSM-5 diagnostic criteria for this mental illness.

\section{The Personality Traits Related to Lady Audley's Antisocial Behaviour}

In the first chapter, the early description a reader encounters of Lady Audley is that of a person endowed with beauty, charm, grace, loveliness and attractiveness:

"Miss Lucy Graham was blessed with that magic power of fascination, by which a woman can charm with a word or intoxicate with a smile. Everyone 
loved, admired, and praised her... Lucy Graham was the sweetest girl that ever lived." (Braddon, 2019) She is depicted as an angelic figure not only for her physical appearance: "They were the most wonderful curls in the world-soft and feathery, always floating away from her face, and making a pale halo round her head when the sunlight shone through them" (10) but also for her demeanour: "it was a part of her amiable and gentle nature always to be light-hearted, happy and contented under any circumstances. Wherever she went she seemed to take joy and brightness with her." (8) As a result, LA was at the centre of the attention of practically everyone in her social circles, an aspect which is related to self-centredness, a common pathological trait of antisocial personality. The attention-seeking behaviour suggested at the beginning of the novel reflects the initial ability of LA to mislead everybody by appearing as an extraordinary governess and a perfect companion (Seys, 2019). As a matter of fact, she is remarkably able to attire the admiration and the respect of her employer, the Dawson family, who can affirm to the entire society that LA is highly qualified as instructor and, additionally, her outstanding qualities make her also a potential wife: “... her employer; his visitors; her pupils; the servants; everybody, high and low, united in declaring that Lucy Graham was the sweetest girl that ever lived." (5) She is the governess who can paint, embroider, read novels and instruct young girls but this is eventually the pleasant facade which helped her to find her a place in society and, primarily, to conceal her true nature and plans for the future.

Therefore, the first image is that of a person with great qualities, good-mannered, jovial, hearty, handsome and apparently with no flaws or defects but not all those who were familiar with this lady shared the same view. She is a "wax-dollish young person" (36) according to the opinion of Alicia, her stepdaughter, who considers her also as "childish and silly" (52). Interesting is the author's choice of an adolescent to make such remarks about LA's nature: a child, symbol of innocence and authenticity, who questions about the true nature of a young lady. The contrast between these two females is indeed regarded as LA's opposition to her social and sexual role (Moqari, 2015). Alicia is a motherly and caring figure who adheres to the social stereotypes of her time whereas LA is struggling against a male dominant society and a sexist mentality that are the main obstacles to her emancipation. From a sociological perspective, LA's behaviour is unequivocally maladaptive, uncivil and yet outrageous. Moreover, it is possible to have another glimpse of the true nature of LA thanks to two other elements of the text: the painter of the heroine's portrait who could see beyond appearances since the woman in the painting had "... something of the aspect of a beautiful fiend" (75) and the dogs at Audley court who were not well-disposed towards her.

In addition to all these aspects, other antisocial personality traits emerge in this analysis which are represented by deceitfulness and interpersonal exploitation. In particular, the agreement that Sir Michael reaches with LA after the proposal is more similar to a formal contract than to the union of two lovers: "Is 
it a bargain, Lucy?" "Yes." (14) The untrue nature of LA's love and her duplicity is suggested by the feelings Sir Michael experienced after the proposal scene: "there was some strong emotion at work in his breast—neither joy nor triumph, but something almost akin to disappointment... as if he had carried a corpse in his bosom." (14) The term "corpse" used here by Braddon may reflect the lack of emotions and vitality and, in this case, of feelings of love. The same term is used in another chapter to describe the sunset at Audley court: "the very repose of the place grew painful... and you felt as if a corpse must be lying somewhere... so deathlike". (26) This passage apparently foresees the fact that some grievous and wretched event is going to take place, that is the murder mentioned by Luke in the same chapter: "I've heard tell of a murder that was done here." (31) The problem of murder is also mentioned by the narrative voice who underlines the fact that such events may also occur in a relatively calm and peaceful country: "We hear every day of murders committed." (58) The reference to this type of crime is presumably a way to express the rebellion of women. The peaceful land likely represents the passive role of women in society while murder may be the expression of the unacceptable intention of a woman to reverse the social equilibrium established by men (Woolston, 2008). By committing crimes, LA became a different person with higher ambitions which are in discordance to the social restrictions imposed to woman. As such, she becomes a major threat to the tranquillity of a natural system.

In another passage in which Sir Michael declares his love, it is clear that LA is trying to appear as a person of humble and modest nature: "but you ask too much of me!... Do not ask too much of me, then. I cannot be disinterested; I cannot be blind to the advantages of such an alliance. I cannot, I cannot!" (13) Interesting is the fact that the word "cannot" is repeated four times in the same utterance, an aspect that can be related to the times that this woman changed her name, social status and identity throughout the novel. At first she was Helen Maldon, then Helen Talboys, next Lucy Graham and finally Lady Audley. This is a fabrication of personal facts for individual gain by which LA shows dishonesty and conning, additional traits of an antisocial personality. Moreover, lying is another trait which is worth to discuss here. It is evident that LA lies constantly and essentially to everybody of her entourage. She is so tenacious and determined in this embroidering that she can defend herself against the evidence of the facts as presented to her by Robert Audley during their most ferocious confrontation in the lime-walk. The ability to reverse the accusations made to her is remarkable: "You are mad, Mr. Audley!" (288) Impressive is also her strength to tolerate the emotional distress related to such a long interrogation made by a barrister who, in turn, was shocked by her wickedness: "What if this woman's hellish power of dissimulation should be stronger than the truth, and crush him?" (290) The conflictual relationship between Robert and LA is not only a matter of disclosing a secret rather the antagonism of two main characters who represent, respectively, the detective and the criminal, the moral and the immor- 
al as well as the male and the female (Matus, 1993). Therefore, Robert stands for the respectable, righteous, noble, good-mannered model to imitate since he belongs to the upper class whereas LA is the shameful, corrupt, dishonest and inferior example of a person who comes from the lower class and thus likely to be dangerous and insane.

Other traits shown by LA are lack of empathy and of intimacy in interpersonal relationships, for instance, when she is in her room with her maid, Phoebe, she so falsely charming when she says: "you are like me, and your features are very nice, it is only the color that you want". (62) This comment is a clear attempt to cajole the poor servant since it is followed by the request to travel to London for a command: "I want you to do me a favor". It is typical of antisocial personality to use captivation and seduction for individual purposes. In this passage LA is orchestrating a plan to avoid meeting her first husband George Talboys, an aspect that is called premeditation. Premeditation is often associated with lack of remorse in a malevolent and degraded mind and LA shows callousness and clarity of mind in her attempt to kill both George and Robert. She wants to eliminate the obstacles to her social position but, in pursuing her intentions, she often loses her self-control. In different occasions, she shows feelings of anger, she is unaware of the consequences of her actions, she acts impulsively and engages in risky situations like the setting on fire of Luke's Inn. In addition, LA does not care about the physical damage she has possibly caused to all these men and, in the most critical moment of her self-reflection, she tries to find an explanation to her behaviour as shown in the following monologue: "My worst wickednesses have been the result of wild impulses, and not of deeply-laid plots. I am not like the women I have read of... planning out treacherous deeds, and arranging every circumstance of an appointed crime" (314). As a matter of fact, LA will declare herself mad by appealing to issues of inheritance and transmission of madness from her mother instead of considering herself as a person who has committed many crimes. In the end, she was not diagnosed as mentally disturbed by a medical expert Dr. Mosgrove: “... there is no evidence of madness... She committed the crime of bigamy, because... she obtained fortune and position. There is no madness there... She employed intelligent means and she carried out a conspiracy which required coolness and deliberation..." (397)

In Victorian Britain there was not a clear distinction between criminals and mad people. Crime was often associated with immoral behaviour, the so called "moral insanity", and insanity was practically a term used interchangeably for madness. If a person committed a crime, his or her behaviour was therefore considered immoral and, consequently, insane because it represented a deviance from social rules and moral principles. It does not surprise that offenders were initially treated in the same way as mentally disturbed people and, thus, relegated to an asylum for the treatment and correction of their behaviour. These institutions were at the time the social response to the phenomenon and, particularly, to the negative reactions observed in the population such as disgust, ab- 
horrence and fear. In addition, an important issue was the genesis of insanity as different theories were speculated to explain the problem (Bennett, 2015). Firstly, hereditary transmission was a plausible reason when it was possible to demonstrate that a parent or a grandparent was likely affected by some type of mental condition. Secondly, poverty was considered as a stressful factor and potentially responsible for the onset of criminal or immoral practices due to lack of control of individuals' instincts. Thirdly, gender was a determinant aspect since women were biologically at high risk of developing a mental illness in relation to their life cycle, for example menstruation, pregnancy, childbearing and menopause were considered as delicate phases for mental stability. Lastly, race was a predisposing factor to insanity, the so called "lunatics", an aspect which was strongly associated with cultural traditions and religious beliefs.

At this point of the investigation, it is important to apply all these social and medical theorisations to the presumable antisocial personality of LA. Familiar transmission was a possible explanation of the character's behaviour but not sufficient to explain her conduct as underlined by Dr. Mosgrove assessment of the case: "There is latent insanity... The lady is not mad; but she has the hereditary taint in her blood... She has the cunning of madness, with the prudence of intelligence... She is dangerous!" (399) LA's low and miserable social origins are another plausible reason that determined the deviant conduct as LA herself will confess to Sir Michael during the proposal scene: "From my very babyhood I have never seen anything but poverty... Poverty-poverty, trials, vexations, humiliations, deprivations. You cannot tell;... you can never guess what is endured by such as we." (13) LA was a woman who lacked motherly affection as shown in the novel: "I did not love the child, for he had been a burden upon my hands." (372) Whether this aspect was a consequence of some postnatal mental condition, it is not confirmed by Braddon but the abandonment of a child was typically considered as the result of madness.

As already mentioned above, psychiatry was an emerging discipline and not much was known about the etiology and treatment of deviant behaviour or mental disorders. The Italian doctor Cesare Lombroso tried to explain that criminals behaved under the emergence of impulses associated with abnormal physical features, especially of the face and skeleton. This is obviously not the case of LA whose countenance, manners and beauty are widely emphasised throughout the novel. In an era of confusion and divergences about the origin of madness, there was not enough evidence for the correct treatment of those who were affected. This is likely the main reason for the confinement of LA to an asylum and not to a prison, for example. However, the progress of medical research and of psychological assessment that occurred after the end of the nineteenth century has conferred more sophisticated diagnostic tools and instruments to the evaluation of mental disorders, thus allowing an in-depth understanding of antisocial behaviour. Brandon's novel is undoubtedly an attempt to show the inconsistencies of the Victorian society but, most importantly, it offers an excellent comprehension of the mental functioning of a criminal mind. 


\section{Conclusion}

To conclude, what emerges from this investigation is that LA was likely affected by antisocial personality disorder as she manifests practically all the features that are described in the diagnostic criteria of DSM-5. Her personality functioning is stable in time and across different situations: it is the mind of a callous, cold, ruthless, egotistical, manipulative, unlawful psychopathic personality (Prosser, 2018). The "angel" that enchanted everybody at the beginning of the novel turned out to be a demon. The "belle of the county" with her childlike innocence, socially admired, endowed by beauty and richness, the perfect wife, became a monster of wickedness who had to be marginalised from society (Woolston, 2008). At the end of the novel, LA is confined to an asylum for mentally disturbed people far away in France because her behaviour was dangerous and scandalous. It was the only solution in a society in which the role of men was predominant and decisive even in the management of aberrant or deviant behaviour displayed by women. Psychiatry as a medical speciality was starting to emerge, the first specialists being called mad-doctors, and these institutions became the ideal and convenient place for isolation and adequate treatment of cases (Marland, 2013). Not all the cases concerned mentally disordered people but also criminals and, unfortunately, women who were in difficulty with their husbands and families. Insanity was a difficult problem to handle in Victorian society since the public opinion was that the insane, as well as the criminals, had to be confined to an institution and then isolated in order to preserve the tranquillity of the community and the moral integrity of the nation. In the end, Braddon provides considerable elements concerning the criminal mind of her heroine, a person who, according to current medical assessments and diagnostic guidelines, would be diagnosed today as affected by antisocial personality disorder.

\section{Conflicts of Interest}

The author declares no conflicts of interest regarding the publication of this paper.

\section{References}

American Psychiatric Association (2012). DSM-IV and DSM-5 Criteria for the Personality Disorders. https://www.psi.uba.ar/academica/carrerasdegrado/psicologia/sitios_catedras/practicas _profesionales/820_clinica_tr_personalidad_psicosis/material/dsm.pdf

Bennett, S. (2015). Representations and Manifestations of Madness in Victorian Fiction. A Thesis Submitted for the Degree of Master of Arts at The University of Walkato (NZ). http://researchcommons.waikato.ac.nz

Braddon, M. E. (2019). Lady Audley’s Secret. Modern Library Trade Paperback Edition.

Davison, S., \& Janca, A. (2012). Personality Disorder and Criminal Behaviour What Is the Nature of the Relationship? Current Opinion in Psychiatry, 25, 39-45.

http://www.antoniocasella.eu/archipsy/Davison_Janca_2012.pdf

https://doi.org/10.1097/YCO.0b013e32834d18f0 
Hare, R. D. (1996). Psychopathy and Antisocial Personality Disorder: A Case of Diagnostic Confusion. Psychiatric Times, 13, issue 2.

https://www.psychiatrictimes.com/view/psychopathy-and-antisocial-personality-disor der-case-diagnostic-confusion

Marland, H. (2013). Women and Madness. Centre for the History of Medicine. Coventry: University of Warwick.

https://warwick.ac.uk/fac/arts/history/chm/outreach/trade_in_lunacy/research/women andmadness

Matus, J. L. (1993). Disclosure as "Cover-Up": The Discourse of Madness in Lady Audley's Secret. University of Toronto Quarterly, 62, 334-355.

https://www.muse.jhu.edu/article/512456

Moqari, S. (2015). Representation of Mad Woman in Lady Audley's Seccret by Mary Elizabeth Braddon. World Scientific News, 22, 76-90.

http://www.worldscientificnews.com/wp-content/uploads/2015/07/WSN-22-2015-76-9 $\underline{0 . p d f}$

Nsaidzedze, I. (2017). An Overview of Feminism in the Victorian Period [1832-1901]. American Research Journal of English and Literature, 3, 1-20.

https://www.arjonline.org/papers/arjel/v3-i1/12.pdf

Prosser, A. (2018). A Bayesian Account of Psychopathy: A Model of Lacks Remorse and Self-Aggrandizing. Computational Psychiatry, 2, 92-140. https://doi.org/10.1162/CPSY_a_00016

Seys, M. C. (2019). It's All Woman Work from One End to Another: Embroidering the Truth in M.E. Braddon's Lady Audely's Secret. Nineteenth-Century Gender Studies Issue 15.2 (Summer 2019).

https://www.ncgsjournal.com/issue152/seys.html

Woolston, J. M. (2008). Lady Audley as the Cunning "Other": An Economic, Sexual, and Criminal Attack on the Victorian Patriarchal Mindset. In EAPSU Online: A Journal of Critical and Creative Work (pp. 156-168). The English Association of Pennsylvania State Universities.

http://eapsu.org/resources/Documents/EAPSU\%20Online\%20-\%20Volume\%20Five.pd $\underline{f}$ 